\title{
Emerging therapies for hemophilia: controversies and
}

\section{unanswered questions [version 1; peer review: 4 approved]}

\author{
Valder R. Arruda(iD1-3, Bhavya S. Doshi1 ${ }^{1}$, Benjamin J. Samelson-Jones ${ }^{1,2}$ \\ ${ }^{1}$ The Children's Hospital of Philadelphia, Philadelphia, PA, USA \\ 2Perelman School of Medicine, University of Pennsylvania, Philadelphia, PA, USA \\ ${ }^{3}$ Raymond G. Perelman Center for Cellular and Molecular Therapeutics, Philadelphia, PA, USA
}

V1 First published: 24 Apr 2018, 7(F1000 Faculty Rev):489

https://doi.org/10.12688/f1000research.12491.1

Latest published: 24 Apr 2018, 7(F1000 Faculty Rev):489

https://doi.org/10.12688/f1000research.12491.1

\section{Abstract}

Several new therapies for hemophilia have emerged in recent years. These strategies range from extended half-life factor replacement products and non-factor options with improved pharmacokinetic profiles to gene therapy aiming for phenotypic cure. While these products have the potential to change hemophilia care dramatically, several challenges and questions remain regarding broader applicability, long-term safety, and which option to pursue for each patient. Here, we review these emerging therapies with a focus on controversies and unanswered questions in each category.

\section{Keywords}

hemophilia, EHL, NFT, gene therapy

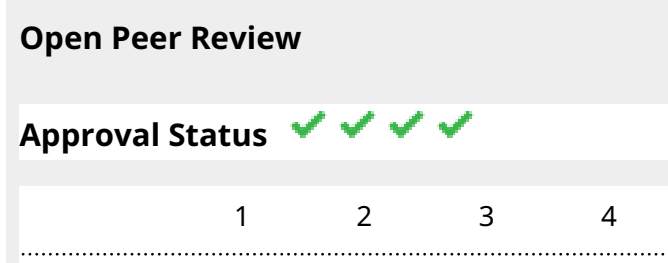

version 1

24 Apr 2018

Faculty Reviews are review articles written by the prestigious Members of Faculty Opinions. The articles are commissioned and peer reviewed before publication to ensure that the final, published version is comprehensive and accessible. The reviewers who approved the final version are listed with their names and affiliations.

1. Qizhen Shi, Medical College of Wisconsin, Milwaukee, USA

2. Pier Mannucci, Fondazione IRCCS Ca' Granda-Ospedale Maggiore Policlinico and University of Milan, Milan, Italy

3. Roland Herzog, University of Florida, Gainesville, USA

4. Steven Pipe, University of Michigan, Ann Arbor, USA

Any comments on the article can be found at the end of the article. 
Corresponding author: Valder R. Arruda (arruda@email.chop.edu)

Author roles: Arruda VR: Writing - Original Draft Preparation, Writing - Review \& Editing; Doshi BS: Writing - Original Draft Preparation; Samelson-Jones BJ: Writing - Original Draft Preparation

Competing interests: BSJ is an investigator on AAV gene therapy clinical trials for hemophilia sponsored by Spark Therapeutics. VRA and BSD declare that they have no competing interests.

Grant information: VRA is supported by 1 R01 HL137335 from NHLBI/NIH.

The funders had no role in study design, data collection and analysis, decision to publish, or preparation of the manuscript.

Copyright: $\odot 2018$ Arruda VR et al. This is an open access article distributed under the terms of the Creative Commons Attribution License, which permits unrestricted use, distribution, and reproduction in any medium, provided the original work is properly cited.

How to cite this article: Arruda VR, Doshi BS and Samelson-Jones BJ. Emerging therapies for hemophilia: controversies and unanswered questions [version 1; peer review: 4 approved] F1000Research 2018, 7(F1000 Faculty Rev):489

https://doi.org/10.12688/f1000research.12491.1

First published: 24 Apr 2018, 7(F1000 Faculty Rev):489 https://doi.org/10.12688/f1000research.12491.1 


\section{Introduction}

Hemophilia is an $\mathrm{X}$-linked bleeding disorder resulting from deficiency of factor VIII (FVIII) or factor IX (FIX) due to mutations in the $F 8$ or $F 9$ genes, respectively. The disorder affects approximately 1 in 10,000 male births worldwide; $80 \%$ of cases are of FVIII deficiency or hemophilia A (HA), and $20 \%$ are FIX deficiency or hemophilia B (HB).

The disease phenotype is characterized by bleeding into the joints (hemarthrosis), skeletal muscle, soft tissues, and enclosed spaces such as the intracranium and retroperitoneum, which can be fatal. Residual factor level correlates directly with bleeding phenotype wherein patients with severe disease $(<1 \%)$ present with spontaneous bleeds, those with moderate disease (1-5\%) bleed with minor trauma and rarely spontaneously, and those with mild disease (6-30\%) bleed only secondary to trauma or invasive procedures. Current treatment includes replacement therapy with plasma-derived ( $\mathrm{pd}$ ) or recombinant $(\mathrm{r})$ clotting factor concentrates either "on demand" for acute bleeding or prophylactically to prevent bleeding. However, in the US, only approximately $60 \%$ of young adults and adults report adherence to prophylaxis, and the average cost of the recommended dose of prophylactic therapy is estimated at approximately $\$ 200,000-300,000 /$ year $^{1}$. Owing to the high cost and need for life-long therapy, only $20 \%$ of patients worldwide have regular access to treatment.

Currently, the most serious complication of hemophilia therapy is the formation of neutralizing alloantibodies (inhibitors) that preclude the hemostatic effect of factor replacement. In HA, $30 \%$ of severe patients and $5-10 \%$ of non-severe patients develop inhibitors compared to only $3-5 \%$ of severe HB patients ${ }^{2}$. Inhibitors are associated with increased morbidity and mortality, and only a few variably effective and expensive hemostatic options (termed bypassing agents) are available to these patients, such as activated prothrombin complex concentrate (aPCC) and recombinant activated factor VII (rFVIIa). Inhibitors do not respond well to immunosuppressive therapy alone ${ }^{3}$. The most efficacious and cost-effective treatment for inhibitors is immune tolerance induction (ITI), which consists of frequent injections of FVIII or FIX for extended periods of time. The success rate of inhibitor eradication is $60 \%$ and $30 \%$ for $\mathrm{HA}$ and $\mathrm{HB}$ patients, respectively ${ }^{4}$. Thus, the development of novel strategies that could facilitate prophylaxis for patients with and without inhibitors is needed (Figure 1).

\section{Extended half-life products}

The half-lives of FVIII and FIX in plasma are 10-12 hours and 16-18 hours, respectively ${ }^{5}$. For prophylaxis, patients with severe disease need to be injected with standard half-life (SHL) replacement therapy two to three times per week to minimize spontaneous bleeds by maintaining a factor level $>1 \%$. Consequently, pharmaceutical development has focused on the optimization of product pharmacokinetics to decrease infusion frequency. Technologies used to create these extended half-life (EHL) products decrease clearance by fusion to the constant fragment (Fc) of IgG or albumin, PEGylation (the covalent attachment of polymeric hydrophilic polyethylene glycol [PEG] molecules), or protein modifications ${ }^{6}$. Alternative strategies to extend

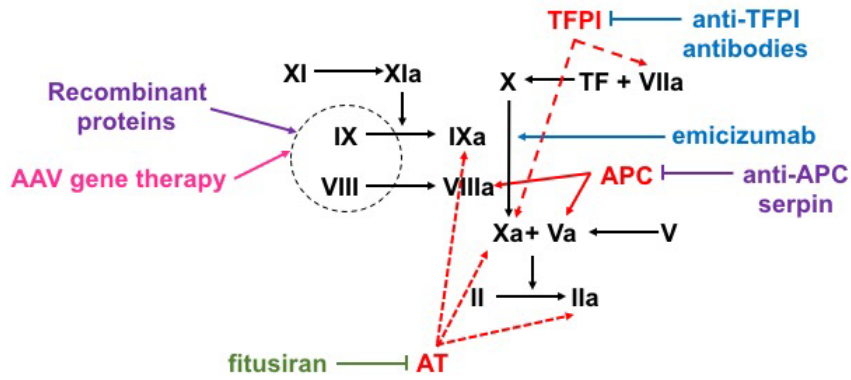

Figure 1. Mechanism of action of hemophilia therapies. Factor $X(F X)$ can be activated to FXa either via FIXa-FVIIla complex or the tissue factor (TF) factor-FVIla complex. FXa and FVa activate prothrombin (FII) to thrombin (FIla) in order to generate a fibrin clot. Natural anti-coagulants targeted by non-factor therapeutics are represented in red. Protein-based therapeutics are represented in purple, nucleotide-based therapeutics are represented in blue, and antibody-based therapeutics are represented in green. Fitusiran decreases the production of antithrombin (AT), decreasing its inhibition of FIXa, FXa, and Flla. Concizumab and antiprotein $\mathrm{C}$ serine protease inhibitors (serpins) block tissue factor pathway inhibitor (TFPI) from inhibiting FXa and TF-FVIIa complex or protein C from inhibiting FVIIla and FVa, respectively. Emicizumab is a FVIla mimic that brings together FIXa and FX to generate FXa. Factor-based therapies include adeno-associated virus (AAV)-based liver-directed gene therapy, which results in endogenous factor production, and exogenously given factor therapeutics given intravenously. APC, activated protein C; EHL, extended half-life.

half-life such as carboxy-terminal peptide technology, hydroxyethyl starch, and hyperglycosylation are still in early preclinical phases. Fusion technologies avoid lysosomal degradation of the protein by utilizing the neonatal Fc receptor to salvage factor proteins and recycle them into the circulation ${ }^{7}$. PEGylation increases half-life by reducing proteolytic cleavage and inhibiting receptormediated clearance ${ }^{8}$.

\section{Are EHL products "better"?}

EHL-rFIX products have successfully decreased infusion frequency from twice weekly to every 10-14 days using fusion to Fc-IgG1 or albumin or PEGylation technologies ${ }^{9,10}$; however, EHL-rFVIII products have only decreased infusions from about three to about two times per week ${ }^{11-13}$. Efforts are underway to understand why EHL-rFVIII products have not been more successful. Clearance of FVIII from the circulation occurs mostly in complex with von Willebrand factor (VWF); the half-life of VWF ranges from 4-26 hours, with an average of approximately 15 hours ${ }^{14}$. The prevailing theory is that the half-life of VWF imposes an upper limit on FVIII half-life prolongation. Two recent studies evaluating the biochemical interaction between VWF and FVIII demonstrated that it was dependent upon the VWF D'D3 and FVIII C1 domains ${ }^{15,16}$. Preclinical studies are now assessing VWF D'D3 and/or FVIII protein modifications to enhance VWF binding or half-life ${ }^{17,18}$. All licensed EHL products recommend tailoring the dose to the individual patient's pharmacokinetic response. Hence, for each individual patient, a particular product may not 
offer significant half-life extension and therefore may be less effective from a cost and convenience standpoint. However, EHL products might afford clinicians the ability to customize a patient's dose and frequency for a higher goal factor trough that minimizes bleeding and maximizes compliance. Indeed, post-hoc analysis of rFVIII-Fc trials demonstrates improved bleeding rate with similar or increased physical activity ${ }^{19}$ and improved joint arthropathy scores in patients treated with rFVIII-Fc either prophylactically or on demand ${ }^{20}$. These benefits likely reflect higher troughs and improved compliance secondary to decreased infusion frequency with EHL products.

\section{Are EHL products safer?}

Whether the EHL products alter the immunogenicity profile of rFVIII products and might be safer than pdFVIII-VWF products is an unanswered question. There is only one reported case of inhibitor development to date for EHL products ${ }^{21}$. Early data support the hypothesis that Fc fusion may potentially decrease immunogenicity in previously treated patients, but analogous data for previously untreated patients are not yet available. To date, seventeen patients with inhibitors have been successfully tolerized with $\mathrm{rFVIII}-\mathrm{Fc}$, including some who had previously failed ITI with SHL rFVIII ${ }^{22-24}$. The success of this strategy is likely due to a longer time with consistent antigen exposure with rFVIII-Fc ${ }^{25}$. Furthermore, in murine studies, treatment with rFVIII-Fc expanded tolerance-inducing regulatory $\mathrm{T}$ cells ${ }^{26}$. A clinical trial for immune tolerance therapy with rFVIII-Fc as first-line therapy is ongoing (NCT03093480). The available data suggest that the immune profile of EHL products is similar to, if not better than, SHL recombinant products. There are no data available comparing recombinant EHL with plasma-derived factors.

However, half-life-extending strategies utilizing protein sequence changes in the bypassing agent rFVIIa have proven problematic. Two different EHL rFVIIa products with changes in protein sequence to enhance stability progressed through early trials, but patients in later-phase trials developed inhibitors to the investigational drug that cross-reacted to endogenous FVIIa ${ }^{27,28}$. These failures underscore the importance of further characterizing the immune response to novel products, especially with amino acid changes, in order to better predict immunogenicity in patients $^{29}$. For PEGylated products, long-term follow-up is needed to understand the implication of anti-PEG antibodies and whether significant PEG accumulation occurs, as was demonstrated in animal models $\mathrm{s}^{30}$. Currently available data suggest that albuminfused rFIX provides a similar dosing frequency to PEGylated rFIX without the theoretical concern of PEG accumulation?

\section{Does switching product affect safety of treatment?}

There are no randomized trial data to understand whether switching a patient from one product to another will change the risk of inhibitor formation. Inhibitors typically occur within the first 50 exposure days to factor in severe patients ${ }^{31}$. Prior studies done after national health services required a change in FVIII product have found varied results ${ }^{32-36}$. Consequently, providers who switch products do so carefully with inhibitor titers pre- and post-switch and generally avoid switching in patients with a history of inhibitor who have been tolerized with a specific product.

The devastating HIV and viral hepatitis epidemics amongst people with hemophilia from viral contamination of plasmaderived products in the 1980's spurred the development and transition to recombinant products ${ }^{37,38}$. However, long-standing debate has ensued in the field regarding the relative immunogenicity of pdFVIII and SHL rFVIII products because of conflicting results of retrospective studies ${ }^{39-42}$. Recently, the only prospective, randomized trial (SIPPET) comparing the immunogenicity of VWF-containing pdFVIII products to SHL rFVIII products in HA demonstrated increased immunogenicity with SHL rFVIII (hazard ratio 1.86$)^{43}$. How best to apply these results in clinical decision making is complicated by the emergence of EHL-rFVIII products since SIPPET. EHL products, especially EHL-rFIX, may increase compliance by decreasing infusion frequencies, but it is unknown if EHL-rFVIII products are more or less immunogenic than SHL rFVIII or pdFVIII products. Although certain factors can guide clinicians to risk of inhibitor formation (e.g. disease severity, underlying mutation, and family history), inhibitor risk stratification is an imprecise science ${ }^{44}$. Furthermore, in SIPPET subanalysis, use of pdFVIII versus SHL rFVIII surprisingly proved beneficial only for "low"- rather than "high"-risk patients ${ }^{45}$. SIPPET results also pose a dilemma for clinicians who are hesitant to return to pdFVIII because of the history of prior bloodborne infectious epidemics or the potential for new ones. Though current virucidal techniques to date have successfully mitigated the risk of emerging viruses (e.g. West $\mathrm{Nile}^{46}$ and $\mathrm{Zika}^{47}$ virus), the risk posed by prions ${ }^{48}$ and other unidentified infectious agents remains unknown. Preliminary data also suggest that EHL products may fare better for ITI, both for those who fail with rFVIII and as first-line therapy ${ }^{22,23}$.

In conclusion, clinicians face a litany of challenging choices for factor replacement. They are tasked with prioritizing convenience, cost, compliance, and safety without definitive ability to predict immune or product pharmacokinetic responses. Though it is tempting to "move backwards" to pdFVIII based upon SIPPET and improved viral inactivation techniques, the potential of a novel blood-borne pathogen epidemic should engender caution. As inhibitors occur in only $20-30 \%$ of severe patients, the economic impact of widespread use of pdFVIII (as implied by recent risk-stratified SIPPET subanalysis ${ }^{45}$ ) should be considered as national groups develop guidelines. Further insight into the basic mechanisms underlying FVIII immunogenicity and clearance, the role of VWF in both, and clear risk stratification schema for inhibitor formation will tremendously advance the ability to identify the best product for each patient.

\section{Non-factor therapies}

Novel technologies aimed at promoting hemostasis in patients with hemophilia without replacing the deficient factor are currently in clinical development. These include FVIII mimics ${ }^{49-52}$ and agents that obstruct the function of natural anti-coagulants, such as antithrombin (AT) ${ }^{53,54}$, tissue factor pathway inhibitor $(\mathrm{TFPI})^{55-59}$, and activated protein C (APC) ${ }^{60,61}$. 
Emicizumab is a bispecific antibody that can simulate the biological function of FVIII sufficiently to produce a pro-coagulant effect in patients with $\mathrm{HA}^{49-52}$. One antigen-binding fragment (Fab) of the bispecific antibody recognizes activated FIX (FIXa), while the other Fab recognizes its substrate, factor X (FX); the simultaneous binding of FX and FIXa by emicizumab sufficiently orients these factors to facilitate the proteolytic activation of FX by FIXa without FVIIIa cofactor activity. Clinical studies have demonstrated that emicizumab is efficacious in decreasing, though not eliminating, the bleeding rate in HA patients with and without inhibitors ${ }^{49,51}$. Encouragingly, the annualized bleeding rate (ABR) of inhibitor patients receiving emicizumab prophylaxis (ABR 2.9) is lower than rates with prophylactic bypassing therapies (ABR 10-36) ${ }^{62,63}$. The rationale of targeting natural anti-coagulants is based on clinical observations ${ }^{64-67}$ and animal model data ${ }^{67,68}$ that demonstrate that a decrease in these anticoagulant pathways may offset the pro-coagulant deficiency in hemophilia and promote hemostasis. Approaches with reported early phase clinical trial results include the AT siRNA therapeutic fitusiran ${ }^{53,54}$ and a monoclonal antibody directed against TFPI $^{55}$, concizumab; both drugs demonstrated encouraging efficacy data. The hemostatic effect of non-factor therapies (NFTs) is impervious to inhibitors. NFTs can also be administered subcutaneously at weekly to monthly frequencies, which is appealing compared to frequent intravenous administrations of standard factor products, though injection site adverse events have been reported in $15-25 \%$ of patients receiving NFTs ${ }^{49,54}$. These attributes have generated considerable excitement; however, how these new treatments will be integrated into clinical practice depends on the resolution of several ongoing debates.

\section{What is the risk of thrombosis from unregulated hemostasis?}

In normal physiology, the endogenous pro-coagulant and anticoagulant pathways are interwoven with multiple regulatory interactions that promote hemostasis (stopping bleeding) while minimizing thrombosis (pathological clotting). NFTs exert their hemostatic effect by circumventing these regulatory interactions in order to therapeutically "rebalance" the coagulation cascade to account for the underlying bleeding disorder ${ }^{69}$. However, the new balance provided by NFTs between hemostasis and thrombosis is likely not as stable as occurs in normal physiology or with targeted factor replacement. This instability is illustrated by the observation that five of the 18 patients on emicizumab prophylaxis who experienced breakthrough bleeding and required management with aPCCs developed thrombotic complications ${ }^{49}$. aPCC is a concentrate of plasma-derived zymogen and activated coagulation factors that has been used for more than four decades to treat bleeding in inhibitor patients ${ }^{70,71}$. Thrombotic complications are rare ( $<10$ per 100,000 infusions) but are a well-recognized risk, especially when combined with other hemostatic therapies such as $\mathrm{rFVIIa}^{70,71}$. It is, therefore, not surprising that the thrombotic complications with emicizumab also occurred when emicizumab was combined with one or more additional bypassing agents. Nevertheless, the increased susceptibility of subjects receiving emicizumab and aPCC to thrombosis suggests a synergistic interplay ${ }^{72-74}$. aPCC contains $\mathrm{FIXa}^{70}$, whose enzymatic activity is enhanced 20,000 -fold by emicizumab ${ }^{52}$ in a biochemically unregulated manner. Emicizumab, unlike FVIII, does not require activation to exert its pro-hemostatic effect, which has been suggested to result in an earlier acceleration of coagulation ${ }^{50}$. As such, there is a biochemical rationale why the concomitant use of emicizumab and aPCC may be especially prothrombotic ${ }^{74}$. These thrombotic complications all occurred in emicizumab prophylaxis subjects who received $>100$ units $/ \mathrm{kg} /$ day of aPCC, which is within the typical dosing recommendations of aPCC ( $<200$ units/kg/day). As FIX and FX provided by aPCC have halflives of 18 and 40 hours, respectively, the potential for accumulation due to multiple administrations raises safety concerns. To date, the risk-mitigation strategy of limiting aPCC doses below this threshold has been successful, and emicizumab was recently approved by the FDA for HA patients with inhibitors.

The risk of thrombotic complications due to unregulated hemostasis is not unique to emicizumab. Though no thrombotic adverse events were observed in the phase I studies, elevated D-dimer levels, a marker of pathological coagulation, were noted in several study participants receiving NFTs targeting $\mathrm{AT}^{54}$ and TFPI ${ }^{55}$. Recently, a phase II study evaluating fitusiran was temporarily suspended after a fatal thrombotic complication ${ }^{75}$. The attractive pharmacokinetic parameters of NFTs that allow for weekly to monthly dosing appear to complicate the management of breakthrough bleeding episodes, as they probably necessitate combination therapies, which will likely increase the risk of thrombotic events. How to safely combine therapies will require thoughtful consideration and empiric studies. This concern raises the question of whether hemophilia patients should be evaluated for thrombophilias prior to starting NFTs. Indeed, one of the five subjects who experienced a thrombotic complication while receiving emicizumab was heterozygous for factor $\mathrm{V}$ Leiden $^{49}$, the most common inherited thrombophilia with a prevalence of approximately $5 \%$ in the Caucasian population ${ }^{76}$. It also suggests the possibility that antidotes for NFTs may be helpful in the treatment of acute bleeds, which are not available currently except for recombinant AT, which should be able to reverse fitusiran.

\section{Are NFTs "better" for all patients?}

The possibility of prophylactic hemostatic coverage while avoiding venipuncture is probably attractive to all patients, but it remains unclear if NFTs will demonstrate better long-term outcomes than factor products for all clinical scenarios. The concerns regarding how best to treat breakthrough bleeding in inhibitor patients receiving NFTs should frame the debate about the role of ITI once NFTs enter clinical practice. ITI is challenging for patients and families; for example, almost $20 \%$ of randomized subjects withdrew from a recent ITI clinical trial ${ }^{77}$. Central venous catheters are almost always required for pediatric patients and are associated with thrombotic and infectious complications ${ }^{77,78}$. However, in the absence of inhibitors, nothing works as well to control and prevent bleeding as factor replacement ${ }^{4}$. Moreover, it is unlikely that NFTs will be able to provide sufficient hemostasis for major surgery or trauma necessitating combination therapy with additional bypassing agents, which are neither as efficacious nor as safe as factor replacement. As such, despite the challenges associated with ITI, successful ITI will likely continue to provide superior long-term clinical 
outcomes compared to NFT prophylaxis with persistent inhibitors. Better risk stratification algorithms ${ }^{4}$ may identify subsets of patients who are very unlikely to tolerize with current ITI regimens, but even these patients may benefit from novel ITI strategies ${ }^{79,80}$ rather than being immediately resigned to life-long NFT prophylaxis. Whether NFT prophylaxis can be combined safely with ITI remains a critical question and requires additional studies.

The preliminary demonstrations of the efficacy of NFTs to prevent bleeding have raised the question of whether these agents will eventually supplant factor replacement as prophylaxis for patients without inhibitors. Current prophylactic regimens are challenging, with almost $40 \%$ of adult patients not routinely receiving prophylaxis ${ }^{81}$. It has also been speculated that subcutaneous delivery of NFTs may allow for earlier initiation of prophylaxis in infants, which could delay factor exposure and potentially prevent inhibitor development ${ }^{82}$. The previous attempt to test this hypothesis, that delaying factor exposure reduces inhibitors through the use of standard bypassing therapy, was unsuccessful owing to breakthrough bleeding ${ }^{83}$, which may be mitigated by increased hemostatic efficacy of new NFTs. However, well-defined relationships between the number of factor exposures and the timing of inhibitor development ${ }^{31,84}$ support this parameter as being the most important rather than the age of exposure; indeed, emerging evidence suggests that earlier exposure to allergens may be protective ${ }^{85}$. Factor exposure in the setting of immunological "danger signals", such as traumatic bleeds or surgery, also increases the risk of inhibitor development ${ }^{86}$. As it is unlikely that NFTs will provide sufficient prophylaxis for patients never to require factor products, NFTs could potentially increase the risk by concentrating exposures to situations with immunological "danger signals". It is possible, however, that the ease of administration of NFTs will attract patients who are currently declining prophylaxis and/or who are noncompliant.

\section{Clinical gene therapy}

Decades of collective effort on the use of adeno-associated virus $(\mathrm{AAV})$ as a vector for hemophilia have culminated with recent successes in long-term expression of therapeutic FVIII and FIX levels, amelioration of the disease phenotype, and reduction or even discontinuation of factor replacement ${ }^{87-89}$. The first inhuman AAV liver gene therapy for HB paved the way for the current successful strategies by showing that AAV can achieve therapeutic levels of functional FIX in a dose-dependent manner, but pre-existing neutralizing antibodies (NAb) to the AAV capsid can prevent liver transduction ${ }^{90}$. These NAb are present in about $40 \%$ of the general population for some AAV serotypes ${ }^{91}$. In addition, an AAV capsid-mediated cellular immune response can limit the duration of the transgene expression and is clinically recognized by an increase in liver enzymes (ALT/AST) and/or decrease in transgene expression levels ${ }^{90,92-94}$. Subsequent trials, therefore, excluded subjects with NAb to the vector capsid and closely monitored for the capsid-directed immune response, which was managed by immunosuppression.

AAV is a single-stranded DNA, non-pathogenic, replication defective virus from the parvovirus family ${ }^{92,95}$. AAV vectors have a package capacity of $4.7 \mathrm{~kb}$, which easily can accommodate FIX cDNA (approximately $1.6 \mathrm{~kb})^{96}$ but was initially challenging for FVIII cDNA ( $7 \mathrm{~kb}$ ) even after the removal of the B-domain (BDD, approximately $40 \%$ of the gene, $4.4 \mathrm{~kb}$ ) that is not required for coagulation function ${ }^{97}$. Consequently, AAV-based gene therapy strategies were initially focused on HB, despite the fact that it is the least common form of hemophilia.

There are several natural AAV serotypes derived from humans and non-human primates as well as synthetic capsids, which are engineered to enhance tissue tropism ${ }^{95}$. All vectors tested in recent clinical trials have high tropism for the liver, which allows delivery via peripheral vein infusion. The expression of the transgene is restricted to hepatocytes by using distinct liver-specific promoters. All studies use codon optimization to enhance transgene expression levels and, in some trials, FIX variants with enhanced biological activity.

\section{What are the current gene therapy clinical studies for hemophilia?}

Results from recent early phase studies are summarized in Table 1. The St Jude Children's Research Hospital and University College of London (SJCRH/UCL) HB study using AAV8 -FIX-WT at doses of $2 \times 10^{11}$ to $2 \times 10^{12} \mathrm{vg} / \mathrm{kg}$ in 10 subjects demonstrated sustained FIX levels ranging from $2-5 \%$ in a dosedependent manner reported over a 3-year period with ongoing observations ${ }^{98,99}$. The transgene is biologically functional as observed by an approximately $90 \%$ decrease in bleeding episodes in the high-dose cohort. However, four out of six subjects presented with increased levels of ALT between weeks 7 and 10 post-vector injection, with some decrease in the FIX levels suggestive of AAV-mediated cellular immune responses. Administration of oral steroids prevented total loss of FIX expression, but prompt ( $<48$ hours) initiation of the drug provided the best outcome. No immune responses were observed in doses $\leq 6 \times 10^{11} \mathrm{vg} / \mathrm{kg}(\mathrm{n}=4)$. In an ongoing study by Spark, an AAV-FIX variant (FIX-Padua) at a low therapeutic dose of $5 \times$ $10^{11} \mathrm{vg} / \mathrm{kg}$ was delivered to 10 subjects $^{100}$. The hyperactive FIXPadua is a protein with approximately eightfold higher specific activity $^{101}$. Thus, it was anticipated that therapeutic levels of FIX could be achieved at a dose fourfold lower than was previously associated with AAV-mediated cellular immune responses in the AAV- $8^{98,99,102}$ and AAV- $2^{90}$ trials. FIX activity reached levels of $30 \%$ without inhibitor formation to FIX-Padua, and prophylaxis with FIX concentrates was stopped in all subjects for a $\geq 3$-month period; long-term follow-up is ongoing. Notably, the rate of immune responses to AAV was lower, as only two out of 10 subjects required immunosuppression. These results demonstrate that FIX-Padua is safe and allows therapeutic levels with a lower risk of vector capsid immune responses. Evidence of FIX-Padua as an attractive transgene was also observed in a previous study by Shire using AAV-8 for $\mathrm{HB}^{103,104}$. Longterm expression was restricted to a single subject $\left(1 \times 10^{12} \mathrm{vg} / \mathrm{kg}\right)$ with FIX activity of $20 \%$. In this study, immunosuppression was not effective at preventing the loss of transgene expression. Again, no inhibitors to FIX-Padua were detected, as was predicted in large animal models ${ }^{105,106}$. 
Table 1. Summary of recently reported AAV gene therapy trial results.

\begin{tabular}{|c|c|c|c|c|c|c|c|c|}
\hline Sponsor & Hemophilia & Vector & Manufacturing & Dose (vg/kg) & $\begin{array}{c}\text { Liver } \\
\text { enzyme } \\
\text { elevation } †\end{array}$ & $\begin{array}{c}\text { Effective } \\
\text { immuno- } \\
\text { suppression? }\end{array}$ & $\begin{array}{l}\text { Transgene } \\
\text { expression } \\
\text { (\% normal) }\end{array}$ & Ref. \\
\hline SJCRH/UCL & $\mathrm{HB}$ & AAV8-FIX-WT & $\begin{array}{l}\text { Plasmid DNA/ } \\
\text { mammalian cell } \\
\text { line }\end{array}$ & $2 \times 10^{11}-2 \times 10^{12}$ & $4 / 6$ & Yes & $2-5 \%$ & 98,99 \\
\hline Spark & $\mathrm{HB}$ & $\begin{array}{l}\text { SPK100-FIX- } \\
\text { Padua }\end{array}$ & $\begin{array}{l}\text { Plasmid DNA/ } \\
\text { mammalian cell } \\
\text { line }\end{array}$ & $5 \times 10^{11}$ & $2 / 10$ & Yes & $\sim 30 \%$ & 100 \\
\hline Shire & $\mathrm{HB}$ & $\begin{array}{l}\text { AAV8-FIX- } \\
\text { Padua }\end{array}$ & $\begin{array}{l}\text { Plasmid DNA/ } \\
\text { mammalian cell } \\
\text { line }\end{array}$ & $2 \times 10^{11}-3 \times 10^{12}$ & NR & No & 0-20\% & 107,108 \\
\hline uniQure & HB & AAV5-FIX-WT & $\begin{array}{l}\text { Baculovirus/ } \\
\text { insect cell line }\end{array}$ & $5 \times 10^{12}-2 \times 10^{13}$ & $2 / 5$ & Yes & $3-12 \%$ & 102 \\
\hline Biomarin & $\mathrm{HA}$ & $\begin{array}{l}\text { AAV5-BDD- } \\
\text { FVIII }\end{array}$ & $\begin{array}{l}\text { Baculovirus/ } \\
\text { insect cell line }\end{array}$ & $6 \times 10^{12}-6 \times 10^{13}$ & $7 / 7$ & Yes & $19-164 \%$ & 109 \\
\hline
\end{tabular}

Abbreviations: AAV, adeno-associated virus; HA, hemophilia A; HB, hemophilia B; NR, not reported; Ref., reference; SJCRH/UCL, St Jude Children's Research Hospital/University College of London; BDD, B-domain deleted.

$\dagger$ (Number of subjects in highest-dose cohort who experienced increased alanine aminotransferase)/(number of subjects in highest-dose cohort)

The uniQure study for HB is based on AAV-5-FIX-WT at doses of $5 \times 10^{12}$ to $2 \times 10^{13} \mathrm{vg} / \mathrm{kg}$ with resulting FIX levels ranging from $3-12 \%$ and nine out of 10 subjects stopped prophylaxis over 1.5 years of observation (ongoing) ${ }^{102}$. However, there was not a clear dose response. An increase in ALT levels occurred in three out of 10 subjects around 10 weeks post AAV injection; all three subjects received steroids and none experienced appreciable FIX activity loss. The HA Biomarin study is based on AAV-5-BDDFVIII. In the high-dose cohort $\left(6 \times 10^{13} \mathrm{vg} / \mathrm{kg}\right)$, sustained expression of FVIII of $19-164 \%$ of normal over a 12-month period was a rather surprising finding (ongoing) ${ }^{109}$. All subjects are off prophylaxis. While an increase in ALT was documented in all subjects from this cohort, and steroids were initiated in all, there was not a clear relationship among ALT normalization, steroid use, and FVIII level stabilization. An additional safety concern raised by the AAV-5 trials is prolonged vector shedding in body fluids, including semen, where samples tested positive for vector sequences for 48 and 52 weeks (yet not cleared) post vector delivery at doses of $5 \times 10^{12} \mathrm{vg} / \mathrm{kg}$ and $6 \times 10^{13} \mathrm{vg} / \mathrm{kg}$ in FIX and FVIII trials, respectively. It is also important to note that age may also influence the vector shedding kinetics from the semen ${ }^{90,110}$. Results from other clinical trials have not been reported.

What should be a feasible and safe therapeutic range? In the early days of gene therapy, the goal was rather modest: minimal increase of factor levels above $1 \%$ could improve the severe phenotype, as noted by both natural history of non-severe disease and prophylaxis. However, in a trial with two subjects with advanced underlying joint disease, FIX levels of 1.5-3\% were not sufficient to prevent bleeds, and prophylaxis was continued ${ }^{98,99}$. Thus, strategies with the potential to achieve $>5 \%$ of normal are likely to be more effective, with some evidence that levels above $12 \%$ could be associated with no spontaneous bleeding ${ }^{111}$. This is rather challenging for those with advanced joint disease who are likely to require surgical intervention despite these therapeutic levels.

In the general population, increased levels of FVIII or FIX are associated with increased risk of thrombosis ${ }^{112-117}$. Supraphysiological levels of FVIII in the HA study raise safety concerns ${ }^{114,115,118}$, since men with hemophilia are not protected from cardiovascular disease and remain at risk of thrombotic complications ${ }^{118}$. In addition, there is no evidence that levels above $50 \%$ of normal are associated with pathological bleeding, and hemophilia carriers have decreased mortality due to ischemic heart disease ${ }^{119}$. The relative short-term follow-up of HA patients expressing elevated levels of FVIII prevent firm conclusions on the safety of this finding.

\section{Is codon optimization of the transgene safe?}

Codon optimization uses synonymous codon changes to increase protein expression without modifying amino acid sequences. The development of numerous codon optimization programs and the commercial availability make this strategy popular. However, there are potential risks, such as the creation of alternative open reading frames and alteration in protein post-translational modifications ${ }^{120}$. As such, for codon optimization, the benefits in gain of expression must be weighed against these safety concerns. To date, the biochemical characterization of a codon-optimized FVIII-BDD that is expressed sevenfold higher than the noncodon-optimized FVIII showed similar, but not identical, biological activity ${ }^{121}$. The transgene used in these studies is the same as that used in the current HA trial by Biomarin ${ }^{122}$.

\section{AAV capsid-mediated T cell responses}

The most common short-term safety concern of AAV gene therapy is the generation of AAV capsid-mediated cellular responses ${ }^{90,92-94}$. This complication is restricted to humans, as provocative preclinical studies in small and large animals failed to 
fully replicate the clinical findings. Encouragingly, this absence of AAV capsid-mediated cellular responses in hemophiliac dogs has resulted in $>8$ years of sustained expression ${ }^{123}$ and created an opportunity for providing a relatively low-risk treatment to HA pet $\operatorname{dogs}^{124}$. In humans, the need for rapid initiation of the immunosuppression therapy to prevent total loss of expression requires a close monitoring of the subjects, which imposes challenging clinical care as studies move beyond early phases. It is not possible to currently identify those who will develop such complications, but some clinical strategies may help to overcome it.

\section{What are the clinical factors triggering immune response to} the vector capsid?

Data from clinical studies show that capsid-mediated immune responses occur with all serotypes in a vector dose-dependent manner. The onset and dose dependence varies among distinct serotypes. For example, in AAV-2 and AAV-8, the dose of $2 \times 10^{12} \mathrm{vg} / \mathrm{kg}^{90,99,100}$ was the threshold for immune responses, whereas for AAV-5 in one study for $\mathrm{HB}^{102,106}$ the dose was 5-10fold higher. Interestingly, in a study using AAV-5 for HA ${ }^{105,109,110}$, only at doses of $6 \times 10^{13} \mathrm{vg} / \mathrm{kg}$ (30-fold higher than AAV-2 and AAV-8 cited above) were immune responses noted. The initial mechanism of elevation of liver enzymes in the trials using AAV-5 was thought to be due to AAV-capsid immune responses. However, in both studies, the dose-dependent increase in liver enzymes was not associated with detectable $\mathrm{T}$ cell expansion. Nevertheless, transient immunosuppression was initiated and liver enzymes normalized. The underlying mechanism of this complication is unclear at this point and may be a direct effect of the vector on the hepatocytes. Therefore, this may influence the long-term safety profile of AAV-5. One possibility for these discrepancies is that AAV-5 vectors were produced using a baculovirus system with insect cells lines, whereas, for the other serotypes, plasmid systems in mammalian cell lines were used. It is known that AAV-5 production in insect cell lines resulted in low infectivity per particle; thus, higher therapeutic vector doses were anticipated $^{125-127}$. Thus, the emerging data suggest that the vector manufacturing process may also influence the safety profile of AAV. To date, a side-by-side comparison of AAV biological activity using distinct manufacturing systems is lacking. Differences in dose needed for therapeutic transgene expression between vectors may account for increased concentration of capsid that is presented to hepatocytes, leading to stimulation of memory T cells.

Is lowering the therapeutic vector dose the safest strategy to avoid immune responses?

The study using AAV-Spark100-FIX-Padua at $5 \times 10^{11} \mathrm{vg} / \mathrm{kg}$ resulted in sustained therapeutic levels of FIX of approximately $30 \%$. Immune responses triggered by AAV capsid occurred in only two out of 10 subjects. In contrast, in the study using AAV-8-FIX-WT at $2 \times 10^{12} \mathrm{vg} / \mathrm{kg}$ (fourfold higher dose), four out of six subjects developed these immune responses ${ }^{99}$. Thus, the use of a transgene with enhanced biological activity allows an effective and safe strategy by minimizing vector-mediated cellular responses. This is also attractive since the AAV-5 trials showed that there is a dose-dependent elevation of the liver enzymes; thus, lowering the therapeutic dose would likely benefit all future studies.

\section{Is $\mathrm{CpG}$ content a risk factor for immune responses to the vector capsid?}

Preclinical studies suggest that activation of innate immune responses through CpG-mediated Toll-like receptor 9 was a potential underlying mechanism for the stimulation of AAV capsid-mediated $\mathrm{CD}^{+} \mathrm{T}$ cell cytotoxicity. The use of CpG-depleted codon-optimized FIX transgene in preclinical models was aimed at high expression level ${ }^{129}$. Notably, the first AAV liver trial using the same FIX transgene resulted in AAV capsid-mediated immune response in four out of six subjects in the high-dose cohort $^{99}$. It is, therefore, probable that the innate immune responses may differ between humans and other species and that simply removing $\mathrm{CpGs}$ will not prevent vector capsid immune responses in patients, though the role of the innate immune response in the anti-AAV capsid cellular immune response deserves continued study ${ }^{130}$. Data on the $\mathrm{CpG}$ content of the other vectors have not been published.

\section{Is transient immunosuppression enough?}

The hepatocyte toxicity triggered by AAV capsid immune responses is clinically asymptomatic and resembles, to a certain extent, autoimmune hepatitis ${ }^{131}$. As such, the use of steroids as the first line of treatment is reasonable. Data suggest that steroids are most effective if initiated within 48 hours after increase of liver enzymes and/or decrease in transgene expression and should be continued for $8-12$ weeks ${ }^{99,128}$. This strategy has been effective in most studies. However, in the Shire-sponsored study, therapeutic levels of FIX (peak at $60 \%$ ) were achieved in the highdose cohort $\left(3 \times 10^{12} \mathrm{vg} / \mathrm{kg}\right)$, but the duration of expression was transient and reduction in expression coincided with increased $\mathrm{ALT}^{103}$. In an AAV-8-FIX clinical study at the Children's Hospital of Philadelphia, three subjects were infused at doses of 1 to $2 \times 10^{12} \mathrm{vg} / \mathrm{kg}$ and all developed an immune response to the vector capsid that was not controlled by immunosuppression, resulting in loss of transgene expression ${ }^{94}$. Alternative immunosuppression regimens may be required ${ }^{132}$.

Whether preventive therapy with steroids would be a more manageable strategy is complicated by the fact that timing of the immune response ranges from 4-10 weeks post vector delivery and depends on the vector serotype. However, it seems that, for a given serotype, the time of immune response onset is very consistent. Thus, if one subject developed immune responses, all subsequent subjects in the same dose cohort could receive prophylactic immunosuppression.

The reasons why immunosuppression can overcome immune response to the vector capsid in some, but not all, studies is unclear. It is possible that the combination of vector design (codon optimization/CpG content), the ratio of empty and full capsid particles, host-dependent factors such as HLA, and the innate ability to mount cellular immune responses could all contribute. Hopefully, as these vector systems and clinical outcomes will be further characterized in future publications, we will likely have more insights on this safety concern. 
Is there a risk of inhibitor formation to the transgene product?

As for any other novel therapy for hemophilia, there are concerns regarding the risk of inhibitor formation. To date, the presence or history of inhibitors and minimal exposure to factor concentrates are exclusion criteria in all of these studies. However, preclinical studies in small and large models showed that AAV liver-restricted expression is biased towards transgenespecific immune tolerance ${ }^{80,133}$. Moreover, in hemophiliac dogs with inhibitor to FVIII or FIX, AAV expression of the transgene was efficacious in inhibitor eradication, mimicking ITI, followed by continuing expression with improvement of the disease phenotype $^{80,105,134}$.

\section{Which strategy is better?}

With growing numbers of clinical studies using diverse strategies, one important issue is to define a superior approach. The simplest outcome measurement, such as sustained factor levels, is a logical criterion. However, if a very high vector dose is needed to achieve high therapeutic levels, the impact on the vector manufacturing to a large patient population may be hampered by production feasibility issues and raises safety concerns. Another possibility is that of a strategy with minimal or no risk of vector-mediated immune responses yet with factor levels in the mild disease range. This could bring the benefits of prophylaxis to a large population without the time-consuming and laborintensive monitoring of ALT and factor levels. Preventive immunosuppression could simplify this process, but, as discussed above, it is not always feasible. Furthermore, the lack of normalization on the strategy used to define the vector genome prevents direct comparison among distinct vectors ${ }^{135}$.

\section{Closing paragraph}

These new therapies will likely transform hemophilia care, providing more efficacious and convenient management options and possibly curative therapies. The largest gains will be accrued by those patients receiving only limited therapeutic benefits from current strategies, such as those with refractory inhibitors and frequent bleeding. However, it is imperative that the excitement over the considerable potential of these drugs to help undertreated patients does not obscure early safety concerns such as potential pathological PEG accumulation, thrombotic complications in NFTs, and irreversible supraphysiological factor levels after gene therapy. Furthermore, the cost of these emerging therapies is not clear; whether these new strategies will expand access to the $80 \%$ of worldwide patients who are currently not receiving regular therapy for economic reasons remains unknown. Hemophilia treaters will have to balance efficacy, convenience, price, and patient preferences and lifestyle when developing personalized treatment plans that include these novel therapies. The hemophilia community is entitled to definitive answers to these questions, which will require careful preclinical and clinical studies. As the types of available therapies become more varied, such studies must include assessments of the quality of life (QoL) of patients. The ultimate goal of therapies for hemophilia is to provide a QoL and life expectancy equivalent to those of someone without a bleeding disorder.

\section{Competing interests}

BSJ is an investigator on AAV gene therapy clinical trials for hemophilia sponsored by Spark Therapeutics. VRA and BSD declare that they have no competing interests.

\section{Grant information}

VRA is supported by 1R01HL137335 from NHLBI/NIH.

The funders had no role in study design, data collection and analysis, decision to publish, or preparation of the manuscript.
1. Johnson KA, Zhou ZY: Costs of care in hemophilia and possible implications of health care reform. Hematology Am Soc Hematol Educ Program. 2011; 2011(1): $413-8$.

PubMed Abstract | Publisher Full Text

2. Key NS: Inhibitors in congenital coagulation disorders. Br J Haematol. 2004; 127(4): 379-91.

PubMed Abstract | Publisher Full Text

3. Laros-van Gorkom BA, Falaise C, Astermark J: Immunosuppressive agents in the treatment of inhibitors in congenital haemophilia A and B--a systematic literature review. Eur J Haematol Suppl. 2014; 76: 26-38. PubMed Abstract | Publisher Full Text

4. Kempton CL, Meeks SL: Toward optimal therapy for inhibitors in hemophilia. Blood. 2014; 124(23): 3365-72.

PubMed Abstract | Publisher Full Text

5. Morfini M: Pharmacokinetics of factor VIII and factor IX. Haemophilia. 2003; 9 Suppl 1: 94-9; discussion 100 PubMed Abstract | Publisher Full Text

6. Mannucci PM: Half-life extension technologies for haemostatic agents. Thromb Haemost. 2015; 113(1): 165-76.

PubMed Abstract | Publisher Full Text

7. Strohl WR: Fusion Proteins for Half-Life Extension of Biologics as a Strategy to Make Biobetters. BioDrugs. 2015; 29(4): 215-39. PubMed Abstract | Publisher Full Text | Free Full Text
8. Ivens IA, Baumann A, McDonald TA, et al.: PEGylated therapeutic proteins for haemophilia treatment: a review for haemophilia caregivers. Haemophilia. 2013. 19(1): 11-20.

PubMed Abstract | Publisher Full Text

9. $\mathrm{F}$ Santagostino $\mathrm{E}$, Martinowitz $\mathrm{U}$, Lissitchkov $\mathrm{T}$, et al.: Long-acting recombinant coagulation factor IX albumin fusion protein (rIX-FP) in hemophilia B: results of a phase 3 trial. Blood. 2016; 127(14): 1761-9.

PubMed Abstract | Publisher Full Text | Free Full Text | F1000 Recommendation

10. F Young G, Collins PW, Colberg T, et al.: Nonacog beta pegol (N9-GP) in haemophilia B: A multinational phase III safety and efficacy extension trial (paradigm ${ }^{\mathrm{TM}}$ 4). Thromb Res. 2016; 141: 69-76.

PubMed Abstract | Publisher Full Text | F1000 Recommendation

11. Konkle BA, Stasyshyn O, Chowdary $\mathrm{P}$, et al.: Pegylated, full-length, recombinant factor VIII for prophylactic and on-demand treatment of severe hemophilia A. Blood. 2015; 126(9): 1078-85.

PubMed Abstract | Publisher Full Text | Free Full Text

12. F Reding MT, Ng HJ, Poulsen LH, et al:: Safety and efficacy of BAY 94-9027, a prolonged-half-life factor VIII. J Thromb Haemost. 2017; 15(3): 411-9. PubMed Abstract | Publisher Full Text | F1000 Recommendation

13. Mahlangu J, Powell JS, Ragni MV, et al:: Phase 3 study of recombinant factor VIII Fc fusion protein in severe hemophilia A. Blood. 2014; 123(3): 317-25. PubMed Abstract | Publisher Full Text | Free Full Text 
14. Pipe SW, Montgomery RR, Pratt KP, et al.: Life in the shadow of a dominant partner: the FVIII-VWF association and its clinical implications for hemophilia A. Blood. 2016; 128(16): 2007-16.

PubMed Abstract | Publisher Full Text | Free Full Text

15. Chiu PL, Bou-Assaf GM, Chhabra ES, et al.: Mapping the interaction between factor VIII and von Willebrand factor by electron microscopy and mass spectrometry. Blood. 2015; 126(8): 935-8.

PubMed Abstract | Publisher Full Text | Free Full Text

16. Yee A, Oleskie AN, Dosey AM, et al:: Visualization of an N-terminal fragment of von Willebrand factor in complex with factor VIII. Blood. 2015; 126(8): 939-42. PubMed Abstract | Publisher Full Text | Free Full Text

17. Pestel S, Raquet E, Mischnik M et al: Half-life Extension of FVIII by Coadministration of a Recombinant D'D3 Albumin Fusion Protein. Paper presented at: Congress of the International Society of Thrombosis and Haemostasis 2017; Berlin, Germany.

18. Chia J, Glauser I, Andrews A, et al: FcRn Mediated Recycling of Recombinant VWF D'D3-albumin Fusion Protein/rVIII-SingleChain Complex Is a Mechanism for FVIII Half-life Extension. Paper presented at: Congress of the International Society of Thrombosis and Haemostasis 2017; Berlin, Germany.

19. F Quon DV, Klamroth R, Kulkarni R, et al.: Low bleeding rates with increase or maintenance of physical activity in patients treated with recombinant facto VIII Fc fusion protein (rFVIIIFc) in the A-LONG and Kids A-LONG Studies. Haemophilia. 2017; 23(1): e39-e42.

PubMed Abstract | Publisher Full Text | F1000 Recommendation

20. F Oldenburg J, Kulkarni R, Srivastava A, et al.: Improved joint health in subjects with severe haemophilia A treated prophylactically with recombinan factor VIII Fc fusion protein. Haemophilia. 2018; 24(1): 77-84 PubMed Abstract | Publisher Full Text | F1000 Recommendation

21. F Giangrande $\mathrm{P}$, Andreeva $\mathrm{T}$, Chowdary $\mathrm{P}$, et al:: Clinical evaluation of glycoPEGylated recombinant FVIII: Efficacy and safety in severe haemophilia A. Thromb Haemost. 2017; 117(2): 252-61

PubMed Abstract | Publisher Full Text | F1000 Recommendation

22. F Malec LM, Journeycake J, Ragni MV: Extended half-life factor VIII for immune tolerance induction in haemophilia. Haemophilia. 2016; 22(6): e552-e4. PubMed Abstract | Publisher Full Text | F1000 Recommendation

23. F Groomes CL, Gianferante DM, Crouch GD, et al:: Reduction of Factor VIII Inhibitor Titers During Immune Tolerance Induction With Recombinant Factor VIII-Fc Fusion Protein. Pediatr Blood Cancer. 2016; 63(5): 922-4. PubMed Abstract | Publisher Full Text | F1000 Recommendation

24. Carcao M, Shapiro A, Staber JM, et al.: Recombinant factor VIII Fc fusion protein for immune tolerance induction in patients with severe haemophilia $A$ with inhibitors-A retrospective analysis. Haemophilia. 2018; 24(2): 245-252. PubMed Abstract | Publisher Full Text

25. Pipe SW: New therapies for hemophilia. Hematology Am Soc Hematol Educ Program. 2016; 2016(1): 650-6.

PubMed Abstract | Publisher Full Text

26. F Krishnamoorthy S, Liu T, Drager D, et al:: Recombinant factor VIII Fc (rFVIIIFc) fusion protein reduces immunogenicity and induces tolerance in hemophilia A mice. Cell Immunol. 2016; 301: 30-9.

PubMed Abstract | Publisher Full Text | Free Full Text | F1000 Recommendation

27. Lentz SR, Ehrenforth S, Karim FA, et al:: Recombinant factor Vlla analog in the management of hemophilia with inhibitors: results from a multicenter, randomized, controlled trial of vatreptacog alfa. J Thromb Haemost. 2014; 12(8): 1244-53.

PubMed Abstract | Publisher Full Text | Free Full Text

28. F Mahlangu J, Paz P, Hardtke M, et al:: TRUST trial: BAY 86-6150 use in haemophilia with inhibitors and assessment for immunogenicity. Haemophilia 2016; 22(6): 873-9.

PubMed Abstract | Publisher Full Text | F1000 Recommendation

29. F Lamberth K, Reedtz-Runge SL, Simon J, et al.: Post hoc assessment of the immunogenicity of bioengineered factor VIla demonstrates the use of preclinical tools. Sci Transl Med. 2017; 9(372): pii: eaag1286. PubMed Abstract | Publisher Full Text | F1000 Recommendation

30. Commitee BPA: BPAC Briefing Document: BLA 125611, Coagulation Factor IX (Recombinant), GlycoPEGylated. In Administration FaD, ed. Washington, D.C. 2017; 1-24.

Reference Source

31. Gouw SC, van der Bom JG, Marijke van den Berg H: Treatment-related risk factors of inhibitor development in previously untreated patients with hemophilia A: the CANAL cohort study. Blood. 2007; 109(11): 4648-54. PubMed Abstract | Publisher Full Text

32. Peerlinck K, Arnout J, Gilles JG, et al.: A higher than expected incidence of factor VIII inhibitors in multitransfused haemophilia A patients treated with an intermediate purity pasteurized factor VIII concentrate. Thromb Haemost. 1993 69(2): 115-8.

PubMed Abstract

33. Rosendaal FR, Nieuwenhuis HK, van den Berg HM, et al.: A sudden increase in factor VIII inhibitor development in multitransfused hemophilia A patients in The Netherlands. Dutch Hemophilia Study Group. Blood. 1993; 81(8): 2180-6. PubMed Abstract

34. White GC 2nd, Courter S, Bray GL, et al:: A multicenter study of recombinant factor VIII (Recombinate) in previously treated patients with hemophilia A. The Recombinate Previously Treated Patient Study Group. Thromb Haemost. 1997; 77(4): 660-7.

PubMed Abstract

35. Giles AR, Rivard GE, Teitel J, et al:: Surveillance for factor VIII inhibitor development in the Canadian Hemophilia A population following the widespread introduction of recombinant factor VIII replacement therapy. Transfus Sci. 1998; 19(2): 139-48.

PubMed Abstract | Publisher Full Text

36. Hay CR, Palmer BP, Chalmers EA, et al.: The incidence of factor VIII inhibitors in severe haemophilia A following a major switch from full-length to B-domaindeleted factor VIII: a prospective cohort comparison. Haemophilia. 2015; 21(2): $219-26$

PubMed Abstract | Publisher Full Text

37. Lee CA: The natural history of HIV disease in haemophilia. Blood Rev. 1998 12(3): 135-44

PubMed Abstract | Publisher Full Text

38. White GC: Hemophilia: an amazing 35-year journey from the depths of HIV to the threshold of cure. Trans Am Clin Climatol Assoc. 2010; 121: 61-73; discussion $4-5$

PubMed Abstract | Free Full Text

39. F Gouw SC, van der Bom JG, Ljung R, et al.: Factor VIII products and inhibitor development in severe hemophilia A. N Engl J Med. 2013; 368(3): 231-9. PubMed Abstract | Publisher Full Text | F1000 Recommendation

40. Iorio A, Halimeh S, Holzhauer S, et al:: Rate of inhibitor development in previously untreated hemophilia A patients treated with plasma-derived or recombinant factor VIII concentrates: a systematic review. J Thromb Haemost. 2010; 8(6): 1256-65

PubMed Abstract | Publisher Full Text

41. Franchini $M$, Tagliaferri $A$, Mengoli $C$, et al:: Cumulative inhibitor incidence in previously untreated patients with severe hemophilia A treated with plasmaderived versus recombinant factor VIII concentrates: a critical systematic review. Crit Rev Oncol Hematol. 2012; 81(1): 82-93.

PubMed Abstract | Publisher Full Text

42. F Lai J, Hough C, Tarrant J, et al.: Biological considerations of plasmaderived and recombinant factor VIII immunogenicity. Blood. 2017; 129(24): $3147-54$.

PubMed Abstract | Publisher Full Text | F1000 Recommendation

43. F Peyvandi F, Mannucci PM, Garagiola I, et al:: A Randomized Trial of Factor VIII and Neutralizing Antibodies in Hemophilia A. N Engl J Med. 2016; 374(21) 2054-64.

PubMed Abstract | Publisher Full Text | F1000 Recommendation

44. DiMichele DM: Inhibitors in childhood hemophilia A: genetic and treatmentrelated risk factors for development and eradication. Pediatr Blood Cancer. 2013; 60 Suppl 1: S30-3.

PubMed Abstract | Publisher Full Text

45. F Rosendaal FR, Palla R, Garagiola I, et al:: Genetic risk stratification to reduce inhibitor development in the early treatment of hemophilia A: a SIPPET analysis. Blood. 2017; 130(15): 1757-9.

PubMed Abstract | Publisher Full Text | F1000 Recommendation

46. Remington KM, Trejo SR, Buczynski G, et al:: Inactivation of West Nile virus, vaccinia virus and viral surrogates for relevant and emergent viral pathogens in plasma-derived products. Vox Sang. 2004; 87(1): 10-8.

PubMed Abstract | Publisher Full Text

47. F Kühnel D, Müller S, Pichotta A, et al.: Inactivation of Zika virus by solvent/ detergent treatment of human plasma and other plasma-derived products and pasteurization of human serum albumin. Transfusion. 2017; 57(3pt2): 802-10. PubMed Abstract | Publisher Full Text | F1000 Recommendation

48. Millar CM: vCJD and hemophilia. Textbook of Hemophilia, 3. 2014; 277-82. Publisher Full Text

49. F Oldenburg J, Mahlangu JN, Kim B, et al:: Emicizumab Prophylaxis in Hemophilia A with Inhibitors. N Engl J Med. 2017; 377(9): 809-818. PubMed Abstract | Publisher Full Text | F1000 Recommendation

50. F Uchida N, Sambe T, Yoneyama K, et al:: A first-in-human phase 1 study of ACE910, a novel factor VIII-mimetic bispecific antibody, in healthy subjects. Blood. 2016; 127(13): 1633-41.

PubMed Abstract | Publisher Full Text | Free Full Text | F1000 Recommendation

51. F Shima M, Hanabusa H, Taki M, et al.: Factor VIII-Mimetic Function of Humanized Bispecific Antibody in Hemophilia A. N Engl J Med. 2016; 374(21): 2044-53.

PubMed Abstract | Publisher Full Text | F1000 Recommendation

52. $\mathrm{F}$ Kitazawa $\mathrm{T}$, Igawa $\mathrm{T}$, Sampei $\mathrm{Z}$, et al:: A bispecific antibody to factors IXa and $\mathrm{X}$ restores factor VIII hemostatic activity in a hemophilia A model. Nat Med. 2012; 18(10): 1570-4

PubMed Abstract | Publisher Full Text | F1000 Recommendation

53. Sehgal A, Barros S, Ivanciu L, et al:: An RNAi therapeutic targeting antithrombin to rebalance the coagulation system and promote hemostasis in hemophilia. Nat Med. 2015; 21(5): 492-7.

PubMed Abstract | Publisher Full Text

54. F Pasi KJ, Rangarajan S, Georgiev P, et al.: Targeting of Antithrombin in 
Hemophilia A or B with RNAi Therapy. N Engl J Med. 2017; 377(9): 819-828. PubMed Abstract | Publisher Full Text | F1000 Recommendation

55. Chowdary $\mathrm{P}$, Lethagen $\mathrm{S}$, Friedrich $\mathrm{U}$, et al:: Safety and pharmacokinetics of anti-TFPI antibody (concizumab) in healthy volunteers and patients with hemophilia: a randomized first human dose trial. J Thromb Haemost. 2015; 13(5): 743-54.

PubMed Abstract | Publisher Full Text

56. Hilden I, Lauritzen B, Sørensen BB, et al:: Hemostatic effect of a monoclonal antibody mAb 2021 blocking the interaction between FXa and TFPI in a rabbit hemophilia model. Blood. 2012; 119(24): 5871-8.

PubMed Abstract | Publisher Full Text

57. Jasuja R, Barakat A, Murphy JE, et al.: An Antibody to Tissue Factor Pathway Inhibitor (TFPI) Restores Hemostasis after the Onset of Bleeding in Hemophilic a Mouse Injury Models. Paper presented at: Annual Meeting of the American Society of Hematology; San Diego, USA. Blood. 2016; 128(22): 3761. Reference Source

58. F Waters EK, Sigh J, Friedrich U, et al.: Concizumab, an anti-tissue factor pathway inhibitor antibody, induces increased thrombin generation in plasma from haemophilia patients and healthy subjects measured by the thrombin generation assay. Haemophilia. 2017; 23(5): 769-76.

PubMed Abstract | Publisher Full Text | F1000 Recommendation

59. $\mathrm{F}$ Gu JM, Zhao XY, Schwarz T, et al:: Mechanistic Modeling of the Pharmacodynamic and Pharmacokinetic Relationship of Tissue Factor Pathway Inhibitor-Neutralizing Antibody (BAY 1093884) in Cynomolgus Monkeys. AAPS J. 2017; 19(4): 1186-95.

PubMed Abstract | Publisher Full Text | F1000 Recommendation

60. F Hamedani NS, Ruhl H, Zimmermann JJ, et al.: In Vitro Evaluation of AptamerBased Reversible Inhibition of Anticoagulant Activated Protein $\mathrm{C}$ as a Novel Supportive Hemostatic Approach. Nucleic Acid Ther. 2016; 26(6): 355-62. PubMed Abstract | Publisher Full Text | F1000 Recommendation

61. Polderdijk SGI, Baglin TP, Huntington JA: Targeting activated protein $\mathrm{C}$ to treat hemophilia. Curr Opin Hematol. 2017; 24(5): 446-52. PubMed Abstract | Publisher Full Text | Free Full Text

62. Antunes SV, Tangada S, Stasyshyn O, et al:: Randomized comparison of prophylaxis and on-demand regimens with FEIBA NF in the treatment of haemophilia A and B with inhibitors. Haemophilia. 2014; 20(1): 65-72. PubMed Abstract | Publisher Full Text | Free Full Text

63. Konkle BA, Ebbesen LS, Erhardtsen E, et al:: Randomized, prospective clinical trial of recombinant factor VIla for secondary prophylaxis in hemophilia patients with inhibitors. J Thromb Haemost. 2007; 5(9): 1904-13. PubMed Abstract | Publisher Full Text

64. Negrier C, Berruyer M, Durin A, et al:: Increased thrombin generation in a child with a combined factor IX and protein C deficiency. Blood. 1993; 81(3): 690-5. PubMed Abstract

65. Kurnik K, Kreuz W, Horneff S, et al.: Effects of the factor V G1691A mutation and the factor II G20210A variant on the clinical expression of severe hemophilia $A$ in children--results of a multicenter studys. Haematologica. 2007; 92(7): 982-5. PubMed Abstract | Publisher Full Tex

66. Escuriola Ettingshausen C, Halimeh S, Kurnik K, et al:: Symptomatic onset of severe hemophilia $A$ in childhood is dependent on the presence of prothrombotic risk factors. Thromb Haemost. 2001; 85(2): 218-20. PubMed Abstract | Publisher Full Text

67. Shetty S, Vora S, Kulkarni B, et al.: Contribution of natural anticoagulant and fibrinolytic factors in modulating the clinical severity of haemophilia patients. Br J Haematol. 2007; 138(4): 541-4. PubMed Abstract | Publisher Full Text

68. Schlachterman A, Schuettrumpf J, Liu JH, et al:: Factor V Leiden improves in vivo hemostasis in murine hemophilia models. J Thromb Haemost. 2005; 3(12): $2730-7$

PubMed Abstract | Publisher Full Text

69. Willyard C: Thrombosis: Balancing act. Nature. 2014; 515(7528): S168-S9. PubMed Abstract | Publisher Full Text

70. Luu $\mathrm{H}$, Ewenstein B: FEIBA safety profile in multiple modes of clinical and home-therapy application. Haemophilia. 2004; 10 Suppl 2: 10-6. PubMed Abstract | Publisher Full Text

71. Turecek PL, Váradi K, Gritsch H, et al:: FEIBA: mode of action. Haemophilia. 2004; 10 Suppl 2: 3-9.

PubMed Abstract | Publisher Full Text

72. Hartmann R, Feenstra T, Knappe S, et al.: Synergistic Interplay of A Sequence Analog of ACE910, a Bispecific Antibody, and a Bypassing Reasgent and its Components. Paper presented at: Congress of the International Society of Thrombosis and Haemostasis; Berlin, Germany. 2017.

73. Yada K, Nogami K, Kitazawa T, et al:: Mode of Enhancement in the Global Hemostatic Potential with Concomitant Use of Bypassing Agents and Emicizumab in Hemophilia A Patients with Inhibitor Evaluated by Rotem Paper presented at: Congress of the International Society of Thrombosis and Haemostasis; Berlin, Germany. 2017.

74. Lenting PJ, Denis CV, Christophe OD: Emicizumab, a bispecific antibody recognizing coagulation factors IX and $X$ : how does it actually compare to factor VIII? Blood. 2017; 130(23): 2463-2468.

PubMed Abstract | Publisher Full Text

75. Alnylam Provides Pipeline Update on Fitusiran and Givosiran Investigational
RNAi Therapeutic Programs [press release]. Cambridge, MA: Business Wire, September 7, 2017.

Reference Source

76. Rees DC, Cox M, Clegg JB: World distribution of factor V Leiden. Lancet. 1995 346(8983): 1133-4.

PubMed Abstract | Publisher Full Text

77. F Hay CR, DiMichele DM, International Immune Tolerance Study: The principa results of the International Immune Tolerance Study: a randomized dose comparison. Blood. 2012; 119(6): 1335-44.

PubMed Abstract | Publisher Full Text | F1000 Recommendation

78. Van Dijk K, Van Der Bom JG, Bax KN, et al.: Use of implantable venous access devices in children with severe hemophilia: benefits and burden. Haematologica. 2004; 89(2): 189-94.

PubMed Abstract

79. Batsuli G, Meeks SL, Herzog RW, et al:: Innovating immune tolerance induction for haemophilia. Haemophilia. 2016; 22 Suppl 5: 31-5.

PubMed Abstract | Publisher Full Text

80. Arruda VR, Samelson-Jones BJ: Gene therapy for immune tolerance induction in hemophilia with inhibitors. J Thromb Haemost. 2016; 14(6): 1121-34. PubMed Abstract | Publisher Full Text | Free Full Text

81. F Mazepa MA, Monahan PE, Baker JR, et al:: Men with severe hemophilia in the United States: birth cohort analysis of a large national database. Blood. 2016; 127(24): 3073-81.

PubMed Abstract | Publisher Full Text | Free Full Text | F1000 Recommendation

82. Franchini M, Mannucci PM: Direct oral anticoagulants and venous thromboembolism. Eur Respir Rev. 2016; 25(141): 295-302.

PubMed Abstract | Publisher Full Text

83. Rivard GE, Lillicrap D, Poon MC, et al:: Can activated recombinant factor VII be used to postpone the exposure of infants to factor VIII until after 2 years of age? Haemophilia. 2005; 11(4): 335-9.

PubMed Abstract | Publisher Full Text

84. Eckhardt CL, van Velzen AS, Peters M, et al.: Factor VIII gene (F8) mutation and risk of inhibitor development in nonsevere hemophilia A. Blood. 2013; 122(11): 1954-62.

PubMed Abstract | Publisher Full Text

85. F Du Toit G, Roberts G, Sayre PH, et al:: Randomized trial of peanut consumption in infants at risk for peanut allergy. $N$ Engl $J$ Med. 2015; 372(9): 803-13.

PubMed Abstract | Publisher Full Text | Free Full Text | F1000 Recommendation

86. Lövgren KM, Sondergaard $\mathrm{H}$, Skov $\mathrm{S}$, et al:: Non-genetic risk factors in haemophilia A inhibitor management - the danger theory and the use of animal models. Haemophilia. 2016; 22(5): 657-66.

PubMed Abstract | Publisher Full Text

87. High KA: The gene therapy journey for hemophilia: are we there yet? Hematology Am Soc Hematol Educ Program. 2012; 2012: 375-81. PubMed Abstract

88. Lheriteau E, Davidoff AM, Nathwani AC: Haemophilia gene therapy: Progress and challenges. Blood Rev. 2015; 29(5): 321-8. PubMed Abstract | Publisher Full Text

89. Rogers GL, Herzog RW: Gene therapy for hemophilia. Front Biosci (Landmark Ed). 2015; 20: 556-603. PubMed Abstract | Publisher Full Text | Free Full Text

90. $\quad F$ Manno CS, Pierce GF, Arruda VR, et al: Successful transduction of liver in hemophilia by AAV-Factor IX and limitations imposed by the host immune response. Nat Med. 2006; 12(3): 342-7. PubMed Abstract | Publisher Full Text | F1000 Recommendation

91. Calcedo R, Morizono $\mathrm{H}$, Wang $\mathrm{L}$, et al:: Adeno-associated virus antibody profiles in newborns, children, and adolescents. Clin Vaccine Immunol. 2011; 18(9): 1586-8.

PubMed Abstract | Publisher Full Text | Free Full Text

92. Arruda VR, Samelson-Jones BJ: Obstacles and future of gene therapy for hemophilia. Expert Opin Orphan Drugs. 2015; 3(9): 997-1010.

PubMed Abstract | Publisher Full Text | Free Full Text

93. Mingozzi F, High KA: Immune responses to AAV in clinical trials. Curr Gene Ther 2011: 11(4): 321-30. PubMed Abstract | Publisher Full Text

94. Ertl HCJ, High KA: Impact of AAV Capsid-Specific T-Cell Responses on Design and Outcome of Clinical Gene Transfer Trials with Recombinant AdenoAssociated Viral Vectors: An Evolving Controversy. Hum Gene Ther. 2017; 28(4): 328-37.

PubMed Abstract | Publisher Full Text

95. Srivastava A: In vivo tissue-tropism of adeno-associated viral vectors. Curr Opin Virol. 2016; 21: 75-80. PubMed Abstract | Publisher Full Text | Free Full Text

96. Choo KH, Gould KG, Rees DJ, et al:: Molecular cloning of the gene for human anti-haemophilic factor IX. Nature. 1982; 299(5879): 178-80. PubMed Abstract | Publisher Full Text

97. Lind P, Larsson K, Spira J, et al:: Novel forms of B-domain-deleted recombinant factor VIII molecules. Construction and biochemical characterization. Eur J Biochem. 1995; 232(1): 19-27.

PubMed Abstract | Publisher Full Text 
98. Nathwani AC, Reiss UM, Tuddenham EG, et al:: Long-term safety and efficacy of factor IX gene therapy in hemophilia B. N Engl J Med. 2014; 371(21): 1994-2004.

PubMed Abstract | Publisher Full Text | Free Full Text

99. F Nathwani AC, Tuddenham EG, Rangarajan S, et al.: Adenovirus-associated virus vector-mediated gene transfer in hemophilia B. N Engl J Med. 2011; 365(25): 2357-65.

PubMed Abstract | Publisher Full Text | Free Full Text | F1000 Recommendation

100. F George LA, Sullivan SK, Giermasz A, et al:: Hemophilia B Gene Therapy with a High-Specific-Activity Factor IX Variant. N Engl J Med. 2017; 377(23): 2215-27. PubMed Abstract | Publisher Full Text | F1000 Recommendation

101. Simioni $\mathrm{P}$, Tormene $\mathrm{D}$, Tognin $\mathrm{G}$, et al:: $\mathrm{X}$-linked thrombophilia with a mutant factor IX (factor IX Padua). N Engl J Med. 2009; 361(17): 1671-5. PubMed Abstract | Publisher Full Text

102. Miesbach W, Meijer K, Coppens M, et al.: Gene therapy with adeno-associated virus vector 5-human factor IX in adults with hemophilia B. Blood. 2018; 31(9): 1022-1031.

PubMed Abstract | Publisher Full Text | Free Full Text

103. Chapin J, Rottensteiner H, Scheiflinger F, et al:: An Analysis of Bleeding Rates and Factor IX Consumption in the Phase I/II BAX 335 Gene Therapy Trial in Subjects with Hemophilia B. Paper presented at: Congress of the International Society of Thrombosis and Haemostasis; Berlin, Germany. 2017.

104. Monahan PE, Sun J, Gui T, et al.: Employing a gain-of-function factor IX variant R338L to advance the efficacy and safety of hemophilia $B$ human gene therapy: preclinical evaluation supporting an ongoing adeno-associated virus clinical trial. Hum Gene Ther. 2015; 26(2): 69-81. PubMed Abstract | Publisher Full Text | Free Full Text

105. Crudele JM, Finn JD, Siner JI, et al:: AAV liver expression of FIX-Padua prevents and eradicates FIX inhibitor without increasing thrombogenicity in hemophilia B dogs and mice. Blood. 2015; 125(10): 1553-61. PubMed Abstract | Publisher Full Text | Free Full Text

106. Finn JD, Nichols TC, Svoronos N, et al:: The efficacy and the risk of immunogenicity of FIX Padua (R338L) in hemophilia B dogs treated by AAV muscle gene therapy. Blood. 2012; 120(23): 4521-3. PubMed Abstract | Publisher Full Text | Free Full Text

107. Antun A, Monahan PE, Manco-Johnson MJ, et al.: Inhibitor recurrence after immune tolerance induction: a multicenter retrospective cohort study. J Thromb Haemost. 2015; 13(11): 1980-8.

PubMed Abstract | Publisher Full Text | Free Full Text

108. Monahan PE, Walsh CE, Powell JS, et al.: Update on phase $1 / 2$ open-label trial of BAX335, an adeno-associated virus 8 (AAV8) vector-based gene therapy for program for phemophilia B. Journal of Thrombosis and Haemostasis. 2015; 13: 87.

109. Rangarajan S, Walsh L, Lester W, et al:: AAV5-Factor VIII Gene Transfer in Severe Hemophilia A. N Engl J Med. 2017; 377(26): 2519-30. PubMed Abstract | Publisher Full Text

110. Schuettrumpf J, Liu JH, Couto LB, et al.: Inadvertent germline transmission of AAV2 vector: findings in a rabbit model correlate with those in a human clinical trial. Mol Ther. 2006; 13(6): 1064-73. PubMed Abstract | Publisher Full Text

111. Den Uij IE, Mauser Bunschoten EP, Roosendaal G, et al:: Clinical severity of haemophilia A: does the classification of the 1950s still stand? Haemophilia. 2011; 17(6): 849-53.

PubMed Abstract | Publisher Full Text

112. van Hylckama Vlieg A, van der Linden IK, Bertina RM, et al.: High levels of factor IX increase the risk of venous thrombosis. Blood. 2000; 95(12): 3678-82. PubMed Abstract

113. Kyrle PA, Minar E, Hirschl M, et al.: High plasma levels of factor VIII and the risk of recurrent venous thromboembolism. N Engl J Med. 2000; 343(7): 457-62. PubMed Abstract | Publisher Full Text

114. Koster T, Blann AD, Briët E, et al.: Role of clotting factor VIII in effect of von Willebrand factor on occurrence of deep-vein thrombosis. Lancet. 1995; 345(8943): 152-5.

PubMed Abstract | Publisher Full Text

115. Jenkins PV, Rawley O, Smith OP, et al.: Elevated factor VIII levels and risk of venous thrombosis. Br J Haematol. 2012; 157(6): 653-63. PubMed Abstract | Publisher Full Text

116. Bertina RM: Elevated clotting factor levels and venous thrombosis. Pathophysiol Haemost Thromb. 2003; 33(5-6): 395-400. PubMed Abstract | Publisher Full Text

117. Rosendaal FR: High levels of factor VIII and venous thrombosis. Thromb
Haemost. 2000; 83(1): 1-2.

PubMed Abstract | Publisher Full Text

118. Mannucci PM, Schutgens RE, Santagostino $E$, et al.: How I treat age-related morbidities in elderly persons with hemophilia. Blood. 2009; 114(26): 5256-63. PubMed Abstract | Publisher Full Text

119. Srámek A, Kriek M, Rosendaal FR: Decreased mortality of ischaemic heart disease among carriers of haemophilia. Lancet. 2003; 362(9381): 351-4. PubMed Abstract | Publisher Full Text

120. F Mauro VP, Chappell SA: A critical analysis of codon optimization in human therapeutics. Trends Mol Med. 2014; 20(11): 604-13. PubMed Abstract | Publisher Full Text | Free Full Text | F1000 Recommendation

121. F Shestopal SA, Hao JJ, Karnaukhova E, et al.: Expression and characterization of a codon-optimized blood coagulation factor VIII. J Thromb Haemost. 2017; 15(4): 709-20.

PubMed Abstract | Publisher Full Text | F1000 Recommendation

122. McIntosh J, Lenting PJ, Rosales C, et al:: Therapeutic levels of FVIII following a single peripheral vein administration of rAAV vector encoding a novel human factor VIII variant. Blood. 2013; 121(17): 3335-44.

PubMed Abstract | Publisher Full Text | Free Full Text

123. Niemeyer GP, Herzog RW, Mount J, et al:: Long-term correction of inhibitorprone hemophilia B dogs treated with liver-directed AAV2-mediated factor IX gene therapy. Blood. 2009; 113(4): 797-806.

PubMed Abstract | Publisher Full Text | Free Full Text

124. Callan MB, Haskins ME, Wang $P$, et al.: Successful Phenotype Improvement following Gene Therapy for Severe Hemophilia A in Privately Owned Dogs. PLoS One. 2016; 11(3): e0151800.

PubMed Abstract | Publisher Full Text | Free Full Text

125. Smith RH, Levy JR, Kotin RM: A simplified baculovirus-AAV expression vector system coupled with one-step affinity purification yields high-titer rAAV stocks from insect cells. Mol Ther. 2009; 17(11): 1888-96.

PubMed Abstract | Publisher Full Text | Free Full Text

126. F Mietzsch M, Casteleyn V, Weger S, et al:: OneBac 2.0: Sf9 Cell Lines for Production of AAV5 Vectors with Enhanced Infectivity and Minimal Encapsidation of Foreign DNA. Hum Gene Ther. 2015; 26(10): 688-97. PubMed Abstract | Publisher Full Text | Free Full Text | F1000 Recommendation

127. Urabe $M$, Nakakura $T$, Xin $K Q$, et al.: Scalable generation of high-titer recombinant adeno-associated virus type 5 in insect cells. $J$ Virol. 2006; 80(4) 1874-85.

PubMed Abstract | Publisher Full Text | Free Full Text

128. George LA, Sullivan SK, Giermasz A, et al.: Hemophilia B Gene Therapy with a High-Specific-Activity Factor IX Variant. N Engl J Med. 2017; 377(23): 2215-27. PubMed Abstract | Publisher Full Text

129. Nathwani AC, Gray JT, McIntosh J, et al:: Safe and efficient transduction of the liver after peripheral vein infusion of self-complementary AAV vector results in stable therapeutic expression of human FIX in nonhuman primates. Blood. 2007; 109(4): 1414-21.

PubMed Abstract | Publisher Full Text | Free Full Text

130. F Rogers GL, Shirley JL, Zolotukhin I, et al:: Plasmacytoid and conventional dendritic cells cooperate in crosspriming AAV capsid-specific $C D 8^{+} \mathrm{T}$ cells. Blood. 2017; 129(24): 3184-95.

PubMed Abstract | Publisher Full Text | Free Full Text | F1000 Recommendation

131. Sebode M, Hartl J, Vergani D, et al:: Autoimmune hepatitis: From current knowledge and clinical practice to future research agenda. Liver Int. 2018; 38(1): 15-22.

PubMed Abstract | Publisher Full Text

132. Arruda VR, Favaro P, Finn JD: Strategies to modulate immune responses: a new frontier for gene therapy. Mol Ther. 2009; 17(9): 1492-503. PubMed Abstract | Publisher Full Text | Free Full Text

133. Sack BK, Herzog RW, Terhorst C, et al:: Development of Gene Transfer for Induction of Antigen-specific Tolerance. Mol Ther Methods Clin Dev. 2014; 1: 14013.

PubMed Abstract | Publisher Full Text | Free Full Text

134. Finn JD, Ozelo MC, Sabatino DE, et al.: Eradication of neutralizing antibodies to factor VIII in canine hemophilia A after liver gene therapy. Blood. 2010; 116(26): 5842-8.

PubMed Abstract | Publisher Full Text | Free Full Text

135. Gavin DK: FDA statement regarding the use of adeno-associated virus reference standard materials. Hum Gene Ther Methods. 2015; 26(1): 3. PubMed Abstract | Publisher Full Text 


\section{Open Peer Review}

\section{Current Peer Review Status:}

\section{Editorial Note on the Review Process}

Faculty Reviews are review articles written by the prestigious Members of Faculty Opinions. The articles are commissioned and peer reviewed before publication to ensure that the final, published version is comprehensive and accessible. The reviewers who approved the final version are listed with their names and affiliations.

\section{The reviewers who approved this article are:}

\section{Version 1}

\section{Steven Pipe}

Pediatrics and Pathology, University of Michigan, Ann Arbor, MI, USA

Competing Interests: No competing interests were disclosed.

\section{Roland Herzog}

Department of Pediatrics, University of Florida, Gainesville, FL, USA

Competing Interests: No competing interests were disclosed.

\section{Pier Mannucci}

Scientific Direction, Fondazione IRCCS Ca' Granda-Ospedale Maggiore Policlinico and University of Milan, Milan, Italy

Competing Interests: No competing interests were disclosed.

\section{Qizhen Shi}

Department of Pediatrics, Medical College of Wisconsin, Milwaukee, WI, USA

Competing Interests: No competing interests were disclosed. 
The benefits of publishing with F1000Research:

- Your article is published within days, with no editorial bias

- You can publish traditional articles, null/negative results, case reports, data notes and more

- The peer review process is transparent and collaborative

- Your article is indexed in PubMed after passing peer review

- Dedicated customer support at every stage

For pre-submission enquiries, contact research@f1000.com 